\title{
MANAJEMEN BRAND IMAGE-CONCEPT AQUA SEBAGAI BRAND BIJAK BERPLASTIK MELALUI PRODUK AQUA LIFE
}

\author{
Astrid Eveline, Hanny Hafiar, Priyo Subekti \\ Fakultas Ilmu Komunikasi Universitas Padjadjaran \\ Jl. Raya Bandung Sumedang KM 21, Jatinangor, Jawa Barat \\ astrid16001@mail.unpad.ac.id
}

\begin{abstract}
This study titled "AQUA Brand Image-Concept Management as a Bijak Berplastik Brand through AQUA Life Product" is a descriptive study with qualitative data type that focuses on knowing AQUA Brand Image-Concept Management as a Bijak Berplastik Brand through AQUA Life product. This study aims to answer questions regarding; 1) step of Consumer Needs Matching, 2) step of Identify Potential Brand Image, 3) step of Identify the Brand Concept, and 4) step of Selecting Brand Image-Concept Strategy on Brand Image-Concept Management as a Bijak Berplastik Brand through AQUA Life product. Data collection techniques used included interviews with eight key informants, non-participatory observation, and literature study. Technical validity of the data using source triangulation. The results of this study revealed that; 1) AQUA has carried out ideal consumer matching needs, but can still be optimized by categorizing products, segmenting benefits, and current needs of consumers that are done more specifically, 2) AQUA is still not optimal in identifying potential brand images, where AQUA has not done the verification process data in market research, 3) AQUA is still not optimal in identifying brand concepts, namely in mapping experiential abstractions delivered to consumers through AQUA Life products, 4) AQUA is still not optimal in selecting potential brand image-concepts, that is, it has not distributed its products to all distribution channels where product availability has an influence on buying interest and attractiveness of consumers to the desired product AQUA Life can form the brand image of AQUA as a Bijak Berplastik brand.
\end{abstract}

Keywords: brand image management; brand concept; brand image-concept; AQUA Life

\begin{abstract}
Abstrak
Penelitian dengan tajuk "Manajemen Brand Image-Concept AQUA Sebagai Brand Bijak Berplastik Melalui Produk AQUA Life" ini merupakan penelitian deskriptif dengan jenis data kualitatif yang berfokus untuk mengetahui Manajemen Brand Image-Concept AQUA Sebagai Brand Bijak Berplastik melalui produk AQUA Life. Penelitian ini bertujuan untuk menjawab pertanyaan mengenai; 1) tahap Consumer Needs Matching, 2) tahap Identify Potential Brand Image, 3) tahap Identify the Brand Concept, dan 4) tahap Selecting Brand Image-Concept Strategy pada Manajemen Brand Image-Concept AQUA sebagai brand Bijak Berplastik melalui produk AQUA Life. Teknik pengumpulan data yang digunakan antara lain adalah wawancara dengan delapan key informant, observasi non-partisipatif, serta studi kepustakaan. Teknis validitas data menggunakan triangulasi sumber. Hasil dari penelitian ini mengungkapkan bahwa; 1) AQUA sudah melakukan consumer needs matching dengan ideal, namun masih dapat dioptimalkan dengan pengkategorian produk, segmentasi manfaat, serta current needs konsumen yang dilakukan lebih spesifik, 2) AQUA masih belum optimal dalam melakukan identifying potential brand images, dimana AQUA belum melakukan proses verifikasi data dalam market research, 3) AQUA masih belum optimal dalam melakukan identifying brand concept, yaitu dalam memetakan abstraksi experiential yang disampaikan
\end{abstract}


kepada konsumen melalui produk AQUA Life, 4) AQUA masih belum optimal dalam melakukan selecting potential brand image-concept, yaitu belum menyalurkan produknya kepada seluruh saluran distribusi dimana ketersediaan produk memiliki pengaruh kepada minat beli dan daya Tarik konsumen kepada produk AQUA Life yang diinginkan dapat membentuk brand image AQUA sebagai brand Bijak Berplastik.

Kata-kata Kunci: manajemen brand image; brand concept; brand image-concept; AQUA Life

\section{PENDAHULUAN}

Banyaknya pemberitaan di media dan juga maraknya isu lingkungan yang menarik perhatian masyarakat dan media nasional maupun internasional tentunya memiiki dampak kepada beberapa sector industri. Hal ini dapat dilihat dari beberapa media internasional yang memberitakan tentang isu sampah plastic di Indonesia. Salah satunya merupakan pemberitaan oleh The Asean Post, bahwa Indonesia menjadi negara ke-2 terbesar penghasil sampah plastic di lautan setiap tahunnya, dimana dilansir dari Lingkunganhidup.co, bahwa sebanyak 11,9\% (kedua terbesar) dari sumber sampah plastic tersebut merupakan limbah air minum dalam kemasan.

Menurut data Dinas Lingkungan Hidup Pemprov DKI Jakarta dan Gerakan Indonesia Diet Kantong Plastik, ibukota menjadi penyumbang 2,5 juta ton sampah setiap tahunnya. Sekitar 370 ribu ton merupakan sampah plastik dan 178 ribu ton sampah plastik tersebut membebani TPA. Bahkan karena perencanaan penanganan sampah yang buruk ditambah tingkat kesadaran masyarakat yang masih rendah tentang limbah, Indonesia kini menjadi pencemar plastik terbesar kedua di dunia setelah China. Dilansir dari Asumsi.co, bahwa salah satu perusahaan penghasil sampah plastic terbanyak di Indonesia merupakan Danone, dimana Danone merupakan perusahaan utama dari AQUA.

AQUA merupakan salah satu merupakan perusahaan Air Minum Dalam
Kemasan dengan penjualan terbesar dan reputasi yang baik di Indonesia. Menurut Agung dalam tirto.id, AQUA menerima penghargaan BrandZ untuk kategori "The Brand Purpose" Making Lives Better dari WPP and Kantar Millward Brown. WPP and Kantar Millward Brown merupakan lembaga survei global untuk efektivitas iklan, komunikasi strategis, media dan brand equity. Departement Corporate Communications AQUA Grup, Leila Djafaar dalam siaran pers, Jumat (11/8), menyebutkan, penghargaan tersebut didapatkan karena AQUA karena dinilai sebagai brand dengan reputasi yang kuat untuk "membuat kehidupan yang lebih baik" dengan misinya meningkatkan akses air bersih bagi masyarakat Indonesia.

Selaras dengan tujuan bisnis AQUA dan misi komitmen ganda untuk kemajuan bisnis dan sosial, Danone memiliki tujuan membangun masa depan yang lebih sehat dari gaya hidup yang sehat, bumi yang sehat dan ekosistem yang sehat. Melihat banyaknya konsumsi kemasan saat ini, dimulai sejak 5 Juni 2018, Danone-AQUA melakukan peneguhan komitmen untuk menjadi pelopor penyelesaian sampah plastik di Indoensia melalui tiga komitmen penting yaitu Pengumpulan Botol Plastik, Edukasi dan Inovasi sebagai upaya penyelesaian masalah sampah plastik di Indonesia. Disaat bersamaan untuk mewujudkan tujuan tersebut, DanoneAQUA dengan semangat kolaborasi dan 
partisipasi aktif bekerja bersama mitra dan konsumen dalam sebuah gerakan baru yang dinamakan Bijak Berplastik. Gerakan ini bertujuan untuk membangun budaya baru yaitu budaya daur ulang dan kesadaran serta keterlibatan dalam menjaga lingkungan.

PT. Tirta Investama meluncurkan produk AQUA Life dimana produk ini diluncurkan pada saat kampanye Bijak Berplastik yang merupakan bentuk perwujudan salah satu dari empat pilar dalam gerakan Bijak Berplastik yaitu inovasi produk yang berbeda dengan competitor lainnya, dan merupakan solusi bagi perusahaan dalam mengantisipasi kekhawatiran perusahaan atas isu plastic yang berdampak kepada image brand AQUA sendiri. Melalui produk AQUA Life yang merupakan produk $100 \%$ terdiri dari plastic recycle dan dapat di recycle, AQUA ingin membentuk brand image bahwa AQUA sudah memiliki inovasi dan kontribusi langsung terhadap kepedulian dan tanggung jawab perusahaan sebagai salah satu penyumbang sampah plastik terbanyak di Indonesia yaitu dalam bentuk kemasan air minum.

Melalui produk AQUA Life, AQUA berharap produk ini dapat menjadi peolopor sebagai produk recycle dan sebagai representasi dari bentu kontribusi perusahaannya sebagai brand air minum dalam kemasan yang Bijak Berplastik. Dalam melakukan perancangan konsep produk AQUA Life yang merupakan kategori packaging innovation, AQUA mengalami keterbatasan waktu dalam melalukan riset kepada konsumen. Hal ini diungkapkan Herbert Slamet selaku Packaging Innovation Development, bahwa AQUA berusaha mencarikan solusi terbaik dan tercepat kepada konsumennya mengenai produk apa yang sebenarnya diinginkan konsumen untuk menyelesaikan isu sampah plastic tersebut, dimana data riset akan digunakan kepada strategi produk lainnya. Keterbatasan waktu tersebut membuat AQUA masih terus melakukan riset kedepannya untuk terus menyesuaikan kemauan konsumen dan meminimalisir kesalahan pengambilan data.

Selain itu pada Frequently Asked Question (FAQ) halaman website AQUA, terdapat banyak pertanyaan konsumen yang mengeluhkan bahwa kemasan produk AQUA Life terasa lembek dan kurang nyaman ketika digunakan, hal ini berpengaruh terhadap pengalaman penggunaan produk yang menurut AQUA sendiri atau experience tepatnya pada sensorik konsumen ketika mengonsumsi produk AQUA Life. Dimana menurut AQUA sendiri, pengalaman konsumsi produk baik dari segi isi maupun packaging memiliki pengaruh terhadap kepuasan konsumen yang akan berdampak pada loyalty dan image brand dimata konsumen.

Pada pembentukan brand image AQUA melalui produk AQUA Life, AQUA merasakan bahwa masyarakat belum banyak mengetahui dan dapat merasakan perbedaan antara produk AQUA Life dan AQUA lainnya sehingga sulit untuk menciptakan persepsi dan opini masyarakat yang akan membentuk brand image AQUA Bijak Berplastik sendiri. Hal ini dibuktikan dengan pernyataan dari beberapa konsumen yang telah mengetahui produk AQUA Life namun belum menjadikan produk ini sebagai top of mind dari brand image AQUA Bijak Berplastik ini sendiri.

Oleh sebab itu peneliti tertarik untuk meneliti lebih lanjut mengenai langkahlangkah Manajemen Brand Image-Concept oleh Lawson dan Balakhrisna (1998) dalam 
AQUA Sebagai Brand Bijak Berplastik Melalui Produk AQUA Life.

Penelitian ini bertujuan untuk (1) mengetahui tahap Consumer Needs Matching pada Manajemen Brand ImageConcept AQUA sebagai brand Bijak Berplastik melalui produk AQUA Life, (2) mengetahui tahap Identify Potential Brand Image pada Manajemen Brand ImageConcept AQUA sebagai brand Bijak Berplastik melalui produk AQUA Life, (3) mengetahui tahap Identify the Brand Concept pada Manajemen Brand ImageConcept AQUA sebagai brand Bijak Berplastik melalui produk AQUA Life, (4) mengetahui tahap Selecting Brand ImageConcept Strategy pada Manajemen Brand Image-Concept AQUA sebagai brand Bijak Berplastik melalui produk AQUA Life.

Berdasarkan Lawson \& Balakhrisna (1998) (2018) merupakan tahapan yang terdiri dari (1) Product CategoryConsumer Needs Matching, (2) Identifying Potential Brand Images, (3) Identifying the Brand Concept, (4) Selecting a Brand Image-Concept Strategy yang pada setiap tahapnya tersebut berkontribusi dalam manajemen brand image-concept suatu brand melalui suatu produk.

Tahapan pertama yaitu Product Category-Consumer Needs Matching dimana berdasarkan Lawson \& Balakhrisna (1998:123) perusahaan harus melakukan riset terkait beberapa hal untuk mengetahui kesamaan dari produk dan yang dibutuhkan oleh konsumen yaitu dengan mengetahui (1) Kategori Produk, (2) Manfaat Produk, dan (3) Current Needs dari konsumen dalam menggunakan produk tersebut, melihat konsumen potensial, serta melihat kategori produk untuk mengetahui mengetahui perbedaan yang ditawarkan dari produknya serta mengetahui produk lain yang memiliki kategori yang sama.

Tahap kedua yaitu Identify Potential Brand Image dimana berdasarkan Lawson \& Balakhrisna (1998:123) hal-hal yang mendorong proses identifikasi potential brand images yaitu perusahaan dapat menghubungkan dengan keadaan pasar dengan melakukan riset pemasaran untuk mengetahui market concern dan communication isssues yang dapat dikembangkan melalui produk ini. Dimana riset pasar terdiri dari (1) Research Objective Preparing, (2) Research Design, (3) Data Collecting, (4) Data Analysis, dan (5) Hasil Riset.

Tahap ketiga yaitu Identify the Brand Concept pada Manajemen Brand ImageConcept berdasarkan Lawson \& Balakhrisna (1998:123) bahwa perusahaan harus menentukan brand concept yang paling potensial dalam produk ini untuk mempermudah dalam merancang berbagai strategi komunikasi dan memudahkan pemetaan produk secara abstraksi. Pada tahapan ini produk dibagi kedalam 3 abstraksi yaitu (1) Functional, (2) Symbolic, dan Experiential.

Tahap keempat yaitu Selecting Brand Image-Concept Strategy berdasarkan Lawson \& Balakhrisna (1998:123) perusahaan harus menyocokkan brand concept dan brand image yang diinginkan dan menerjemahkannya mengikuti prinsip integrated marketing communication. Pada tahap ini perusahaan harus melakukan (1) Menentukan brand image, (2) Marketing Mix.

\section{METODE PENELITIAN}

Penelitian ini merupakan penelitian kualitatif dan bersifat deskriptif, yaitu penelitian yang bertujuan menggambarkan dan menelaah permasalahan yang ada pada masa sekarang. Penelitian kualitatif 
adalah penelitian yang bermaksud untuk memahami fenomena tentang apa yang dialami oleh subjek penelitian secara holistik dan dengan cara deskripsi dalam bentuk kata-kata dan bahasa, pada suatu konteks khusus yang alamiah dan dengan memanfaatkan berbagai metode ilmiah (Moleong: 2007). Pada penelitian ini, produk AQUA Life menjadi focus utama peneliti untuk melihat dan menemukan apakah sudah sesuai dengan konsep brand image-concept management yang dikemukakan oleh Lawson \& Balakhrisna untuk membentuk brand image-concept AQUA sebagai brand Bijak Berplastic.

Informan yang dipilih oleh peneliti adalah: (1) Herbert Slamet selaku Packaging Development Manager PT. Tirta Investama, (2) Amanda Umihani selaku Marketing Innovation Manager PT. Tirta Investama, (3) Romie Johanes selaku Marketing Innovation Director PT. Tirta Investama, (4) Dian Savita Putri selaku Sustainable Development Manager PT. Tirta Investama, (5) Tama Situmorang selaku Assistant Brand Manager PT. Tirta Investama, (6) Jeffri Ricardo selaku Brand Manager PT. Tirta Investama, (7) Gilang Sasmoyo selaku PR \& Media Relations Danone Indonesia, dan (8) Dimas Adityo selaku Business Development Manager PT. Tirta Investama.

Peneliti menggunakan jenis purposive sampling dikarenakan peneliti telah mempertimbangkan dan menganggap bahwa sampel yang ditunjuk atau ditentukan oleh peneliti sudah memenuhi kriteria berdasarkan tujuan penelitian dan dapat memberikan informasi yang akurat bagi penelitian yang dilakukan.

Dalam penelitian ini, peneliti menggunakan (1) Observasi, (2) Wawancara, (3) Studi Pustaka dan (4) Dokumentasi. Adapun bentuk observasi yang digunakan dalam penelitian ini adalah observasi partisioatif dimana peneliti melakukan job training, mengumpulkan data dengan wawancara mendalam, dan mencatat kegiatan yang sedang berjalan. Dalam observasi ini peneliti hanya mengamati tetapi tidak ikut serta dalam semua aktivitas tersebut (Sugiyono, 2010:62)

Peneliti melakukan wawancara terstruktur yang dimana peneliti melakukan atau menanyakan pertanyaan kepada informan berdasarkan pedoman wawancara yang telah dibuat sebelumnya. Hal ini ditujukan untuk mencegah kesalahan informasi yang didapat oleh peneliti dalam mencari data.

Selain memperoleh data dengan cara observasi serta wawancara, peneliti juga memperoleh data atau fakta dari profil perusahaan atau company profile milik PT Tirta Investama (AQUA) dan media sosial instagramAQUA (@sehataqua) itu sendiri.

Sementara itu, keabsahan data pada penelitian ini dilakukan metode triangulasi. Triangulasi dalam pengujian kredibilitas diartikan sebagai pengecekan data dari berbagai sumber dengan berbagai waktu. Menurut (Sugiyono, 2012: 270) uji keabsahan data dalam penelitian kualitatif adalah untuk menguji, credibility, transferability, dependability, dan confirmability pada data yang telah diperoleh. Peneliti menggunakan triangulasi sumber dalam penelitian ini. Triangulasi sumber dilakukan kepada Romilda yaitu seorang dosen Hubungan Masyarakat di Universitas Mercu Buana dan seorang Humas Universitas Indonesia.

\section{HASIL DAN PEMBAHASAN}

Dalam membentuk dan me-manage brand image diperlukan beberapa langkah konstruktif yang digunakan untuk menjawab beberapa urgensi atau permasalahan komunikasi pada suatu brand atau perusahaan, dan juga diperlukan management yang diperlukan untuk mengerti abstrak dari konsep yang 
mewakili value atau arti dari brand tersebut secara jangka panjang. Park, Jaworski, \& MacInnis (1986) mengatakan bahwa essential insight memiliki peran penting dalam mengembangkan dan mengelola brand image yang terletak pada interaksi yang konstruktif antara brand image tertentu yang diciptakan untuk memecahkan beberapa permasalahan komunikasi saat ini, dan pemahaman manajemen tentang abstrak brand concept yang mewakili makna jangka panjang merek tersebut (Lawson \& Subra, 1998, p. 121).

Product Category-Consumer Needs Matching terdiri dari tiga poin yaitu kategori produk, manfaat produk, dan current needs.

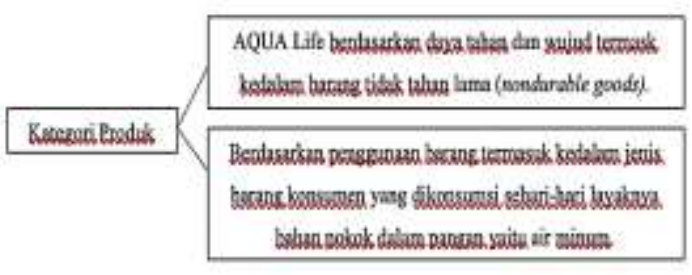

Gambar 1. Kategori Produk.

Sumber: Data Wawancara

\section{Model 1 Kategori Produk}

Berdasarkan pernyataan dari Kotler \& Armstrong (1996:274) bahwa produk dapat diklasifikasikan menjadi beberapa kelompok, yaitu berdasarkan daya tahan dan wujud, serta penggunaannya.

Produk AQUA Life telah dikategorikan produk AQUA Life menjadi produk barang tidak tahan lama (nondurable goods) dikarenakan walaupun produk air minum ini dapat dikonsumsi hingga jangka waktu panjang, produk ini akan habis jika dikonsumsi satu atau beberapa kali, dan juga produk AQUA Life termasuk kedalam jenis barang konsumen (convenience goods) dimana produk ini merupakan barang yang biasanya sering dibeli konsumen dengan cepat dengan upaya yang sangat sedikit.

Degeratu

mengklasifikasikan produk di sebagai sensorik vs non-sensorik. Kategori ini disarankan karena banyaknya transaksi online yang dilakukan saat ini dikalangan konsumen dan berbeda dari pertukaran tradisional dalam hal atribut sensorik produk seperti sentuhan, bau atau suara. Dalam hal ini mengingat AQUA juga melakukan transaksi online pada produk AQUA Life, AQUA dapat mengklasifikasikan produknya menjadi produk sensorik atau non-sensorik agar mengetahui informasi ataupun strategi apakah yang tepat untuk disampaikan ke konsumen karena berpengaruh terhadap persepsi, pengalaman, dan daya beli konsumen terhadap produk AQUA Life.

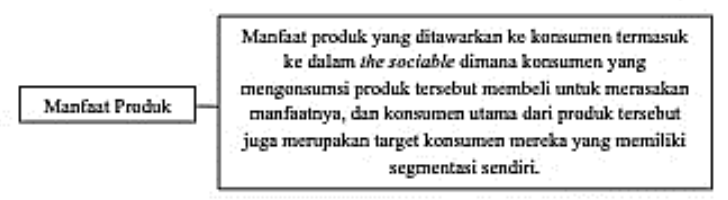

Gambar 2. Manfaat Produk Sumber: Data Wawancara

\section{Model 2 Manfaat Produk}

Menurut Haley (1968:30) Segmentasi manfaat dipandang memiliki jangkauan aplikasi yang jauh lebih luas daripada metode dan teknik segmentasi tradisional karena memberikan pemasar gambaran yang lebih lengkap tentang pelanggan, mulai dari profil motivasi mereka hingga karakteristik perilaku atau sosial ekonomi yang mungkin berguna dalam penentuan posisi atau strategi promosi. Lewis (1981) menjelaskan segmentasi manfaat kemudian didefinisikan ulang sebagai 'mengelompokkan pelanggan pada dasar pentingnya mereka lampirkan pada kombinasi sensorik, rasional, dan manfaat emosional yang diharapkan dari produk atau layanan. 
Dalam hal ini, manfaat produk AQUA Life yang tergolong kepada segmentasi the sociable, dimana AQUA menginginkan konsumennya, terutama target konsumen dari segmentasi tersebut membeli produknya dikarenakan mengetahui fungsi dari produk yang ditawarkan, yaitu hidrasi sehat, dan kemasan sustainable. Dalam hal ini AQUA mendapatkan hasil profil dari konsumen potensialnya dari hasil segmentasi benefit, segmentasi the sociable pada produk AQUA Life menunjukkan bahwa produk ini berpotensi untuk dikonsumsi pada konsumen dengan kriteria berkegiatan aktif, memiliki ketertarikan dengan sesuatu yang sama, seperti pola hidup sehat dan sustainable pada umumnya memiliki peer group, dimana mereka berusaha untuk menjalankan pola hidup atau suatu tujuan yang sama.

Berdasarkan Frochot \& Morrison (2016:403) manfaat dapat dibagi berdasarkan fungsional dan psikologis dan merujuk pada apa yang dikenal sebagai faktor pendorong dan penarik. Kelompok manfaat pertama terkait dengan atribut fungsional. Kelompok kedua adalah manfaat sosial-psikologis yang berkaitan dengan interaksi sosial, dll. Dalam hal ini tidak menutup kemungkinan suatu produk dapat menawarka kedua jenis manfaat fungsional dan psikologis mengingat suatu produk pasti memiliki karakteristik mengikuti referensi grup terkait. Hal ini juga diperkuat ole Ahmad (2003:6) bahwa segmentasi manfaat memungkinkan untuk mengidentifikasi pelanggan khusus dari kelompok konsumen yang lebih besar dan heterogen . Dalam hal ini AQUA dapat mengoptimalkan pengkategorian produknya menjadi produk dengan manfaat fungsional dan psikologis karena memiliki fungsi dan manfaat sosial-psikologis yang ditawarkan bagi target konsumennya.

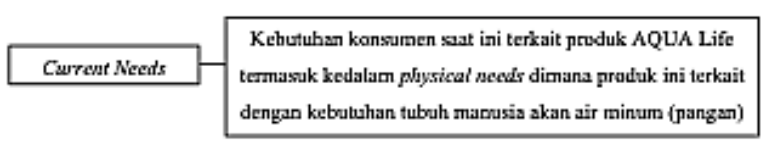

Gambar 3. Current Need

Sumber: Data Wawancara

\section{Model 3 Current Needs}

Berdasarkan pernyataan dari Maslow (1943:370) membagi menjadi lima macam kebutuhan manusia, yaitu: (1) Physical Needs yaitu kebutuhan fisik merupakan kebutuhan yang berhubungan dengan kondisitubuh seperti pangan, sandang, dan papan, (2) Safety Needs yaitu kebutuhan ini lebih bersifat psikologi individu dalam kehidupan sehari-hari, (3) Social Needs yaitu kebutuhan ini juga cenderung bersifat psikologis dan sering kali berkaitan dengan kebutuhan lainnya, (4) Esteem Needs yaitu kebutuhan ini menyangkut prestasi dan prestise individu setelah melakukan kegiatan, (5) Self Actualization yaitu kebutuhan ini merupakan kebutuhan tertinggi dari individu dan kebutuhan ini sekaligus paling sulit dilaksanakan.

AQUA sudah mengkategorikan current needs dari konsumennya yaitu pada physical needs yaitu kebutuhan yang berhubungan dengan fisik atau tubuh yaitu pangan dimana konsumen membutuhkan hidrasi melalui air minum untuk sehariharinya, namun konsumen ingin produk air minum yang berkualitas, memenuhi ketersediaan produk, dan lebih ramah lingkungan dimana hal-hal tersebut akan sangat berpengaruh terhadap keputusan pembelian terhadap brand dan jenis produk dalam memenuhi kebutuhan sehari-hari konsumen.

Menurut Zeithaml $\quad$ (2018:3)
menekankan bahwa pentingnya
menghitung minat beli kembali konsumen
untuk mencari tahu pelanggan yang tetap
setia atau meninggalkan suatu barang dan
jasa. Minat pembelian konsumen menurut


Basrah \& Samsul (2018:3) yaitu: (1) Minat Transaksional; Kecenderungan konsumen untuk selalu membeli ulang produk yang telah dikonsumsinya, (2) Referensi Minat; Kesediaan konsumen untuk Menerima produk yang telah dikonsumsinya untuk orang lain, (3) Minat Preferensial; Perilaku konsumen yang Menjadikan produk yang telah dikonsumsinya sebagai pilihan utama, (4) Minat Eksploratif; Harapan konsumen untuk selalu mencari informasi tentang produk yang diminatinya. Dengan mengoptimalkan analisis minat konsumen ini, AQUA akan mengetahui seberapa potensial konsumen dalam membeli produk AQUA Life secara berulang, apakah sesuai atau tidak dengan minat konsumen, dan apakah akan digunakan secara continue.

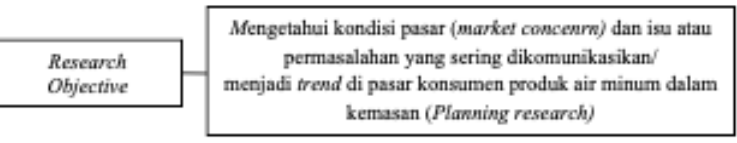

Gambar 4. Research Objective Preparing

Sumber: Data Wawancara

\section{Model 4 Research Objective Preparing}

Menurut Ariestonandri (2006:15) Reseach Objective Preparing berdasarkan tujuannya, riset pemasaran dapat diklasifikasikan menjadu tiga kelompok, meski dimungkinkan adanya kombinasi. Ketiga jenis riset itu adalah: (1) Problem Solving Research, yakni riset yang diadakan untuk mengidentifikasi dan memecahkan masalah-masalah pemasaran., (2) Controlling Research, yakni riset yang diadakan untuk pengawasan atau mengendalikan proses bisnis dan pemasaran yang sedang berjalan., (3) Planning research, yakni riset yang diadakan untuk mendapatkan informasi sebagai panduan merencanakan kegiatan pemasaran.

Jenis objective dari riset yang dilakukan AQUA terhadap produk AQUA Life termasuk ke dalam jenis planning research dimana riset ini yang diadakan untuk mendapatkan mendapatkan informasi sebagai panduan merencanakan kegiatan pemasaran yang terukur dan sebagai panduan merencanakan kegiatan pemasaran produk AQUA Life.

Kerlinger dan Lee (2000) research objective atau tujuan riset sebaiknya berkisar dari yang sangat umum, seperti laba maksimalisasi, ke yang sangat spesifik, seperti mengukur minat pasar pada produk baru. Setiap studi harus memiliki serangkaian tujuan yang sangat terbatas dan dapat dikelola yang berfokus pada masalah sedang dipecahkan. Dua atau tiga tujuan yang ditargetkan dengan baik lebih untuk melacak kemajuan menuju tujuan, untuk memastikan bahwa masingmasing ditangani dengan benar, dan untuk menentukan metodologi terbaik. Kerlinger dan Lee menyarankan bahwa masalah penelitian dan hipotesis memenuhi kriteria: (1) Pernyataan masalah menyatakan hubungan antara dua atau lebih variable, (2) Masalahnya dinyatakan dengan jelas dan jelas dalam bentuk pertanyaan, (3) Pernyataan masalah menyiratkan kemungkinan pengujian empiris.

Dalam hal ini, AQUA dapat merumuskan masalah penelitian dan hipotesis yang sesuai dengan kriteria yang diusulkan oleh Kerlinger dan Lee untuk mengetahui apa yang harus dilakukan peneliti, konsep hipotesis juga dapat berguna dalam penelitian untuk mengarahkan keputusan pengembangan pernyataan masalah penelitian.

Research Design

Menggunakan jenis riset desain descriptive reseanch untuk mengetahui segmentasi konsumen potensial, ,situasi pasar, promosi ataupun konsep produk seperti apa yang mereka sukai untuk produk AQUA Life

Gambar 5. Research Design

Sumber: Data Wawancara

\section{Model 5 Research Design}

Menurut Parasuraman, Aaker, Emory, Cooper \& Maholtra (2006:23) 
desain riset pemasaran terbagi tiga jenis desain, yaitu: (1) Exploratory research atau desain riset penjajakan, umumnya masalah yang akan dipecahkan belum terdefinisi secara pasti, (2) Descriptive research bertujuan memahami gambaran atau deskripsi kasus pemasaran secara mendetil, yang dapat mengacu pada jenis pertanyaan $5 \mathrm{~W}+1 \mathrm{H}$, (3) Cause effect research design atau riset sebab akibat, bertujuan untuk mengidentifikasi hubungan sebab akibat dari variabel-variabel kasus pemasaran.

Desain riset yang dilakukan AQUA untuk riset pasar produk AQUA Life yaitu menggunakan descriptive research untuk mengetahui segmentasi konsumen potensial, AQUA ingin mengetahui apa yang terjadi di pasar mereka (what), pada saat kapan tren/isu tersebut terjadi (when), segmentasi konsumen manakah yang paling berpotensial (who), berada dimana sajakah konsumen potensial tersebut (where), bagaimanakah kegiatan promosi dan konsep produk yang mereka sukai (how), dan mengapa merekai menyukai hal tersebut (why).

Wiley, (1998:83) menyatakan penelitian deskriptif harus mendefinisikan pertanyaan, responden yang akan disurvei, dan metode analisis sebelum pengumpulan data awal. Dengan kata lain, aspek $5 \mathrm{~W}+1 \mathrm{H}$ harus didefinisikan. Ada dua jenis dasar penelitian deskriptif: (1) Studi Longitudinal dan Studi Cross-sectional. Studi longitudinal adalah analisis deret waktu yang melakukan pengukuran berulang pada individu yang sama untuk memonitor perilaku seperti penggantian merek. Studi cross-sectional untuk melakukan pengukuran pada titik waktu tertentu, jenis ini melacak sekelompok individu yang mengalami peristiwa yang sama dalam interval waktu yang sama dari waktu ke waktu. Jenis analisis berguna untuk peramalan jangka panjang akan permintaan produk (Wiley, 1998, p. 83).. Dimana jenis analisis ini sangat cocok untuk digunakan dalam riset produk AQUA Life untuk mengetahui peramalan jangka panjang akan produk tersebut.

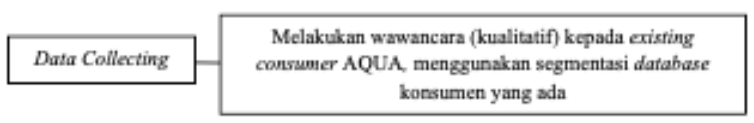

Gambar 6. Data Collecting

Sumber: Data Wawancara

\section{Model 6 Data Collecting}

Data collecting menurut Ariestonandri (2006:71) merupakan tahap pengumpulan data berupa FGD, in depth interview, projective technique, atau desk research ini membutuhkan waktu cukup lama. Estimasi waktu tergantung pada cakupan wilayah survey, metode sampling yang digunakan, dan tingkat kesulitan memperoleh responden. Hal tersebut dapat dibantu menambah staff nterviewer/observer atau menggunakan database calon responden yang sudah ada.

AQUA melakukan proses data collecting dilakukan oleh research agency dengan melaukan wawancara (kualitatif) kepada konsumennya, dengan target konsumen yaitu semua segmentasi konsumen semua produk AQUA (existing consumer), menggunakan segmentasi database konsumen yang ada yaitu search quaries, food basket, business objective, media moments, reason to buy, socio-demo index, interest, dan engagement. Proses data collecting dilakukan oleh research agency dengan melakukan focus group interview dan in-depth interview kepada konsumennya. Data collecting dilakukan kurang lebih 3 minggu di beberapa kota besar seperti Jakarta, Surabaya, Yogyakarta, dan Bali, dimana mereka merasa konsumen potensial dari existing consumer AQUA pada produk AQUA Life berada di daerah-daerah tersebut (Region 1 \& BALINUSRA). Proses data collecting yang dilakukan AQUA dan research agency sudah sesuai dengan menurut 
Ariestonandri dan sudah dapat mengumpulkan data responden dengan cukup spesifik sesuai dengan sample yang diinginkan.

Menurut Wiley (1998:83) metode pengumpulan data primer yang paling umum penelitian pemasaran pada survey dapat berupa : (1) Pribadi: Informasi dicari melalui wawancara pribadi. Kuesioner disusun dan diberikan kepada responden selama wawancara, (2) Telepon: Ini cocok jika informasi yang terbatas dicari secara tetap jangka waktu. (3) Mail: Di sini, kuesioner dikirim melalui pos. Respons tepat waktu tidak dapat dicari dalam metode ini karena tidak ada kontrol atas survei. Terkadang kombinasi dari dua metode atau lebih dapat digunakan untuk mengecek validitas data pada tahap ini ataupun verifikasi. Dalam verifikasipun menurut Hyman \& Sierra (2015:6) terdapat pertanyaan awal untuk memulai pengumpulan data, (1) Siapakah yang akan mengumpulkan data?, (2) Seberapa lamakah proses pengambilan data yang direncanakan? (3) Berapa banyak pengawasakah yang dibutuhkan?. Dengan menjawab pertayaan-pertanyaan ini di awal sebelum memulai pengumpulan data, perusahaan atau AQUA dapat memproyeksikan dan memantai research agency yang digunakan untuk tenggang waktu, jumlah responden, serta pengawasan agar data yang dikumpulkan diyakinin validitasnya.

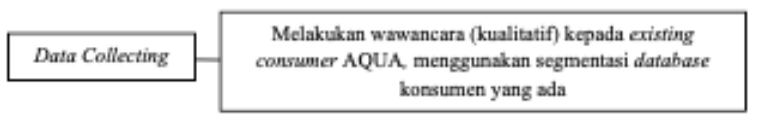

Gambar 7. Data Analysis

Sumber: Data Wawancara

\section{Model 7 Data Analysis}

Menurut Miles dan Huberman (1994:269) proses data analysis terbagi menjadi 3 bagian, yaitu (1) Data Reduction, Pengurangan data mengacu pada proses pemilihan, pemfokusan, penyederhanaan, pengabstrakan, dan transformasi data yang muncul dalam catatan lapangan tertulis atau transkripsi, (2) Data display, tampilan data berjalan selangkah lebih jauh dari reduksi data untuk menyediakan kumpulan informasi terorganisir dan terkompresi dapat menjadi sepotong teks atau diagram, bagan, atau matriks, (3) Conclusion Drawing and Verification, kesimpulan untuk mempertimbangkan apa arti data yang dianalisis dan menilai implikasinya. Verifikasi, yang terkait secara integral dengan gambar kesimpulan, mengharuskan mengunjungi kembali data sebanyak mungkin waktu yang diperlukan untuk memeriksa silang atau memverifikasi kesimpulan.

Proses data analysis yang dilakukan dalam market riset ini dilakukan sepenuhnya oleh pihak research agency. Data reduksi dengan memisahkan data hasil wawancara konsumen yang lengkap, jelas, dan error. Data hasil wawancara dipisahkan berdasarkan segmentasi konsumen yang sesuai pada database AQUA agar mudah mengetahui karakteristik existing consumer yang ada, dan agar data dapat digunakan untuk keperluan internal perusahaan yang lain. Proses data display dilakukan dengan mengutip pernyataan konsumen dan juga membuat bagan/tabel untuk memetakan hasil data. Pengutipan dilakukan juga sesuai dengan segmentasi konsumen AQUA, dibagi berdasarkan karakteristik yang diperlukan oleh perusahaan seperti yaitu search quaries, food basket, business objective, media moments, reason to buy, socio-demo index, interest, engagement, dan berdasarkan profil dan segmentasi umur konsumen. Hasil data disimpulkan dan diverifikasi dalam sebuah tabel, namun pihak agency dan perusahaan AQUA tidak melakukan pemeriksaan kembali (verification) terhadap data yang diambil dan telah di analisis dikarenakan adamua keterbatasan waktu dan kondisi yang 
kurang memungkingkan untuk melakukan pengunjungan kembali

Menurut triangulator, proses analisis data sangat penting dilakukan oleh kedua pihak yaitu AQUA dan agency, karena dapat meminimalisir permasalahan yang terjadi selama proses riset sekaligus membantu dalam pengecekkan kembali atas validitas data. Pengecekkan kembali validias data jika mengalami keterbatasan dapat menggunakan metode lain, seperti telpon karena dinilai masih efektif untuk mengetahui kejujuran responden.

Hal ini selaras dengan pernyataan Smith \& Albaum (2012:72) dalam mengumpulkan data dalam riset akan lebih baik untuk melakukan survey pretest dan pilot untuk memberikan informasi yang membantu dalam mengelola potensi kesalahan penelitian dan membuat survei lebih efisien dan efektif dalam jangka panjang. Pretesting akan menjawab dua pertanyaan apakah pertanyaan dan questioner sudah tersusun dengan baik. Pretesting tidak menjamin bahwa kuesioner (atau bahkan survei) akan valid, namun dapat membantu untuk menyocokkan survey dan membantu menentukan ukuran sampel yang diperlukan untuk survei actual dan memperkuat validitas data dari awal karena sampel yang terpilihpun sudah melalui pilot atau pretesting. AQUA dapat melakukan pretesting sebagai antisipasi jika tidak dapat melakukan validitas data unuk membantu menentukan sampel dan validitas.

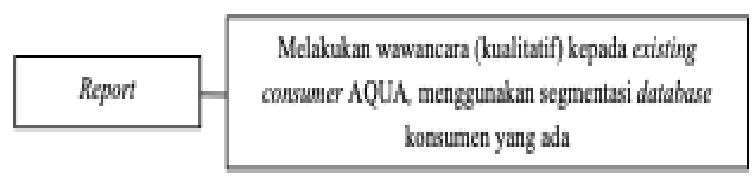

Gambar 8. Result

Sumber: Data Wawancara

\section{Model 8 Result}

Menurut Mariampolsk (2015:10) membagi laporan presentasi akhir penelitian menjadi beberapa jenis, yaitu : topline atau executive summary, summary report, full report, oral presentations, video presentation, dan computer presentation.

Hasil dari riset ini dipresentasikan oleh pihak agency kepada pihak AQUA dalam bentuk oral presentation yang berjudul AQUA Consumer Tribes. Dimana dari hasil penelitian konsumen tersebut dapat disimpulkan bahwa konsumen AQUA saat ini memiliki keinginan dan mencoba untuk gaya hidup lebih sehat dan sustainable dan tentunya menginkan produk lokal yang memiliki kualitas yang baik dan mendukung pola hidup mereka. Namun pihak agency ataupun pelaku riset juga dapat menyiapkan beberapa hal sebelum mempresentasikan hasil riset.

Menurut Hyman \& Sierra (2015:10) hal yang lebih baik dilakukan sebelum mempresentasikan hasil analisis data final kepada pihak perusahaan (biasanya posisi senior management) hal ini dilakukan untuk meminimalir dan menerima feedback akhir dari perusahaan agar presentasi berjalan baik yaitu dengan membuat tabel dummy. AQUA dapat membuat dummy atau tabel kosong yang harus dilengkapi begitu hasil analisis data tersedia untuk membantu menuliskan feedback laporan dari pemegang keputusan setelah selesai dianalisis, agar hasil riset yang dipresentasikan kepads senior atau top management sudah sesuai dengan model presentasi perusahaan tersebut agar lebih mudah dimengerti. 


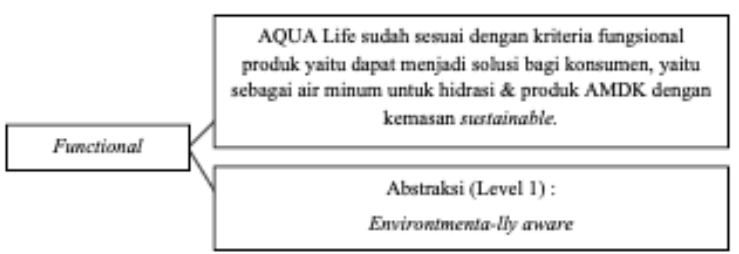

Gambar 9. Functional

Sumber: Data Wawancara

\section{Model 9 Functional}

Menurut Lawson dan Balakhrisna (1998:123) fungsional didefinisikan sebagai yang memotivasi pencarian untuk produk yang memecahkan masalah yang berhubungan dengan konsumsi yang dihasilkan secara eksternal.

Secara fungsional produk AQUA Life memiliki fungsi produk utama yaitu untuk memenuhi kebutuhan hidrasi sehat dari konsumen AQUA sendiri. Untuk fungsi produk kedua yang ingin disampaikan kepada konsumen melalui produk AQUA Life yaitu produk ini dapat membantu konsumen untuk mengurangi konsumsi ataupun produksi plastik sendiri. Secara praktikal, fungsi produk yang dirancang melalui produk AQUA Life telah mememuhi kriteria dari fungsional produk yang menjadi solusi dari masalah dari brand, seperti dapat diandalkan, efisian dan praktis atau nyaman (problem solving capabilities of the brand, such as being reliable, efficient, practical or convienient). Dalam pemetaan berdasarkan abstraksi fungsional produk AQUA Life termasuk kedalam environtmentally aware menyesuaikan dengan konsep yang dirancang dalam kegunaan kemasan produk yang diimplementasikan pada pemetaan A Patrial List on Needs-Based Abstract Brand Concept oleh Lawson dan Balakhrisna (1998:122).

Menurut Park, Jaworski \& Macinnis, pemetaan abstraksi fungsional terbagi menjadi tiga tahap, yaitu introduction, elaboration, dan fortification.
Tahap introduction mengacu pada functional problem solving capabilities dari produk, tahap elaboration mengacu pada problem solving specialization strategy, dan problem solving generalization strategy, tahap fortification mengacu pada image bundling through new products.

Menurut Park, Jaworski \& Macinnis (1986:35) terdapat dua dasar strategi yang dilakukan brand dengan konsep fungsional. (1) problem-solving specialization strategies, dan (2) problemsolving generalization strategies. Problemsolving specialization strategy dapat mengurangi competitor yang memiliki kegunaan dan keuntungan yang sama. Strategi ini berguna saat produk menjadi sangat kompleks dan membutuhkan spesialisasi yang lebih dan pasar menjadi lebih terfragmentasi. Problem-solving generalization strategy adalah strategi kedua untuk meningkatkan nilai dari suatu brand dengan konsep fungsional. Strategi ini akan secara otomatis mengikuti problem-solving specialization strategies. Disini, tujuannya adalah untuk membuat brand berguna pada beberapa situasi penggunaan. Dalam hal ini, AQUA dapat mengkategorikan produknya secara fungsional menggunakan dua dasar strategi yang dilakukan brand dengan konsep fungsional, AQUA dapat menggunakan dasar Problem-solving generalization strategy adalah sebagai strategi untuk meningkatkan nilai brand AQUA melaui produk AQUA Life dengan konsep fungsional, dikarenakan produk ini merupakan produk baru dan belum memiliki competitor dengan konsep produk yang sama, sehingga AQUA dapat menentukan spesialisasi yang lebih dan pasar menjadi lebih terfragmentasi. 


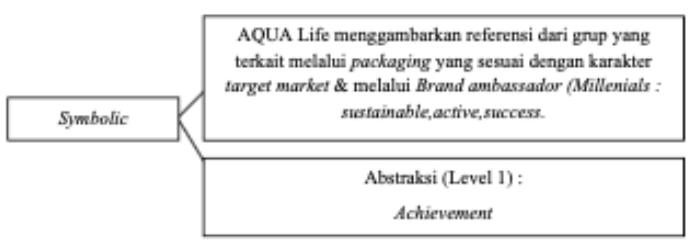

Gambar 10. Symbolic

Sumber: Data Wawancara

\section{Model 10 Symbolic}

Menururt Lawson dan Balakhrisna (1998:123) abstraksi symbolic membicarakan bagaimana suatu produk bisa memiliki referensi suatu grup atau egoechancing associations, serta terkait dengan individual ataupun grup agar dapat mencerminkan image dari produk itu sendiri. Dalam hal ini symbolic dari produk itu sendiri dapat dinilai dari visual produk, keterkaitan atau referensi dari symbol yang ditampilkan pada visual tersebut, dan juga terasosiasi dengan siapakah produk ini apakah dengan individu ataukan dengan grup tertentu sebagai cerminan dari target konsumen produk itu sendiri.

Dimulai dari segi visual sendiri, produk AQUA Life dirancang dengan unsur simbolik tergambar melalui bentuk botol, volume dari botol, warna, typography yang mencakupi jenis, ukuran, dan konten tulisan yang terdapat di botol tersebut. Bentuk dan ukuran botol sendiri terbentuk sedemikian rupa merupakan dampak dari volume AQUA 1100ml yang berbeda dari produk lainnya (differensiasi). Logo AQUA Life merupakan hasil pengembangan logo AQUA dengan symbol recycle yang sudah melekat di masyarakat untuk mempermudah masyarakat mengerti tentang produk ini.

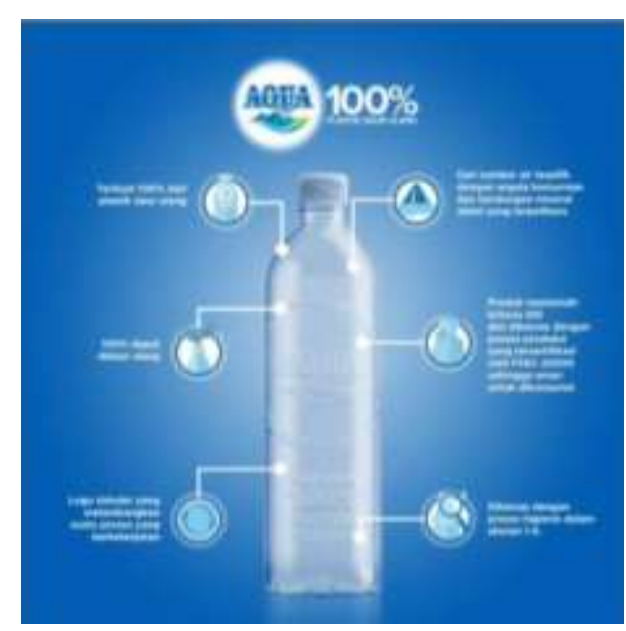

Gambar 11. Visualisasi Produk Aqua Sumber : Arsip Danone-AQUA

Hal ini sudah menyesuaikan dan mengikuti referensi dari grup atau targeted consumer yaitu orang-orang yang peduli akan lingkungan dengan karakter yang aktif digambarkan dengan adanya brand ambassador yaitu Hamish Daud dan Kelly Tandiono untuk mewakili karakteristik targeted market mereka yaitu kategori millennial yang termasuk dalam kategori umur 18-44 tahun, secara demografi tinggal di kota besar, dan memiliki kepedulian akan pola hidup sehat, sustainable, aktif dan memiliki kesuksesan masing-masing (mencerminkan usia produktif). Dalam pemetaan berdasarkan abstraksi symbolic produk AQUA Life menimbulkan korelasi secara simbolik antara konsumen dengan self image dari produk itu sendiri sehingga termasuk kedalam pemetaan Achievement, hal ini menyesuaikan dengan konsep yang dirancang dalam kegunaan kemasan produk yang diimplementasikan pada pemetaan A Patrial List on Needs-Based Abstract Brand Concept oleh Lawson \& Balakhrisna (1998:122).

Menurut Levitt (1986:139) produk dengan abstraksi symbolic dapat dipertahankan meskipun cara-cara spesifik untuk mengkomunikasikan asosiasi simbolik bervariasi dari waktu ke waktu. Sama seperti misalnya memungkinkan untuk perubahan dalam penawaran khusus, 
kebutuhan berubah. demikian juga konsep memungkinkan untuk perubahan dalam gambar tertentu sebagai kebutuhan berubah. Kebutuhan simbolik didefinisikan sebagai keinginan untuk produk yang memenuhi kebutuhan yang dihasilkan secara internal untuk peningkatan diri, posisi peran, keanggotaan kelompok, atau identifikasi ego Maka dari itu AQUA seharusnya dapat mengasosiasikan kebutuhan simbolik yang diinginkan dan dicerminkan suatu kelompok sebagai karakteristik menjadi konsumen potensial.

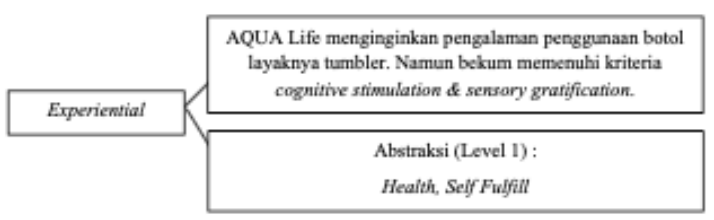

Gambar 12. Experiential

Sumber: Data Wawancara

\section{Model 11 Experiential}

Menurut Lawson dan Balakhrisna (1998:123) experiential berfokus pada aspek cognitive simulation atau sensory gratification pada suatu brand.

AQUA sendiri ingin konsumennya merasakan experience atau pengalaman dengan menggunakan produk ini AQUA ingin membuat konsumennya lebih merasa environtmentally friendly dan menginginkan konsumen memberikan pengalaman penggunaan botol layaknya tumbler, adanya feedback dari konsumen tentang material plastic dan ketebalan kemasan yang menjadikan konsumen merasa kemasan AQUA Life terasa lembek menjadikan konsumen kurang setuju dan puas akan penggunaan produk yang disamakan dengan tumbler. Selain itu visual\&kemasan produk yang terasa lembek dirasa kurang merangsang panca indera dan kognitif sehingga pengalaman yang dirasa tidak sesuai dengan pengalaman sensorik dan kognitif yang diinginkan. Dalam hal pemetaan abstraksi produk AQUA Life termasuk ke dalam Health dan Self Fullfilment dimana menyesuaikan dengan konsep produk serta pengalaman yang diharapkan dirasakan konsumen.

Menurut triangulator konsep experiential terutama pada produk baru sangat diperlukan, selain harus dapat dimengerti tentang pengetahuan produk kepada target konsumennya, perusahaan harus dapat membuat segmentasi konsumen lainnya untuk dapat menerima tentang produk tersebut baik secara fungsional, simbolik, maupun pengalaman yang ingin disampaikan mengenai produk. Hal ini diperlukan untuk menumbuhkan persepsi baik akan produk baru pada konsumen, dan ketika produk mengalami perubahan secara spesifik untuk menyesuaikan kebutuhan target konsumennya, konsumen segmentasi lainpun akan lebih mudah menerimanya, dan awareness dari produk pun akan tetap terjaga.

Menutur Oliver Reicheld (2009:53) AQUA dapat meningkatkan pengalaman konsumen akan produk AQUA Life, dikarenakan pengalaman yang dirasakan konsumen harus memengaruhi kepuasan dan loyalitas konsumen Schmitt (2009:53) mengusulkan lima pengalaman: (1) Sense atau pengalaman indra meliputi estetika dan kualitas sensorik, (2) Feel atau pengalaman merasakan termasuk suasana hati dan emosi,, (3) Think atau pengalaman berpikir mencakup pemikiran konvergen atau analitik dan divergen atau imajinatif,, (4) Act atau pengalaman tindakan mengacu pada aksi motorik dan pengalaman perilaku., (5) Relate atau pengalaman berhubungan mengacu pada pengalaman sosial, seperti berkaitan dengan kelompok referensi.

Dari kelima jenis pengalaman tersebut, AQUA dapat mengoptimalkan pengalaman penggunaan produk AQUA 
Life yang ditawarkan kedalam kelima aspek tersebut. Memang sebagian besar pengalaman penggunaan produk terjadi ketika konsumen berbelanja, membeli, dan mengkonsumsi produk secara langsung melalui activation ataupun kegiatan yang dapat melibatkan konsumen mengerti dan merasakan pengalaman penggunaan ataupun manfaat yang ditawarkan produk, namun pengalaman juga dapat terjadi secara tidak langsung dengan memaksimalkan penggunaan iklan dan komunikasi pemasaran, termasuk situs Web dalam menyampaikan pengalaman penggunaan produk AQUA Life kepada consumen melalui testimoni oleh KOL ataupun konsumen lainnya.

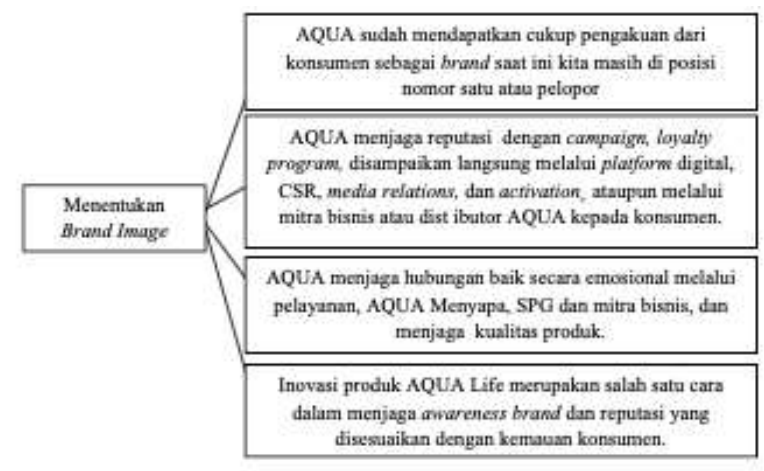

Gambar 13. Menentukan Brand Image Sumber: Data Wawancara

\section{Model 12 Menentukan brand image}

Menurut Hamel \& Praharld (2011), dimensi dari citra merk dibagi menjadi 4 yaitu: (1) Pengakuan (Recognition), kemampuan konsumen untuk mengenal dan mengingat suatu merek dalam benak dan pikiran mereka, (2) Reputasi (Reputations), kekuatan merek yang dapat membangun status yang cukup tinggi bagi sebuah merek karena dimata konsumen suatu merek memiliki suatu track record yang baik, (3) Hubungan emosional (Affinity) merek produk yang dapat membentuk asosiasi positif yang membuat konsumen menyukai suatu produk, (4) Lingkup (Domain) diferensiasi produk, menyangkut seberapa besar lingkup dari suatu produk yang mau atau tertarik menggunakan merek yang bersangkutan.

AQUA sebagai perusahaan air minum sudah mendapatkan cukup pengakuan dari konsumen Psebagai perusahaan air minum dalam kemasan yang telah berdiri selama 47 tahun. Pengakuan dibangun dari banyaknya materi promosional yang dimanage oleh perusahaan. AQUA sendiri menurut riset internal dan eksternal yang kita lakukan setiap tahun kaya seberapa besar awareness dan engagement yang didapatkan oleh brand saat ini kita masih di posisi nomor satu atau pelopor

AQUA menjaga reputasi melalui berbagai campaign, loyalty program, materi edukasi yang disampaikan langsung melalui platform digital, CSR, media relations, dan activation, ataupun melalui mitra bisnis atau distributor AQUA kepada konsumen untuk mejaga reputasi yang baik yang selama ini dibangun melalui informasi mengenai kontribusi perusahaan kepada pihak konsumen lainnya dan juga menjaga dari banyaknya black campaign yang dilakukan competitor dan mempertahankan reputasi dan terus dikenal di segala segmentasi konsumen dari waktu ke waktu.

AQUA menjaga hubungan baik secara emosional melalui pelayanan, AQUA berusaha menjaga kualitas produk dan pelayanan dengan selalu memberikan product knowledge melalui mitra bisnis, kualitas produk yang telah memenuhi standar BPOM dan Halal. Selain itu AQUA juga menjaga pelayanan melalui kanal lainnya pada media sosial, AQUA Menyapa, SPG dan mitra bisnis yang setiap harinya berkomunikasi langsung dengan konsumen dan sebagai salah satu garda terdepan dari perusahaan yang berperan dalam menjaga hubungan baik secara pelayanan dan produk kepada konsumen untuk menjaga loyalitas mereka. 
Melalui produk AQUA Life ini, AQUA berusaha mengkomunikasikan kepada konsumen bahwa kontribusinya dalam bentuk inovasi produk baru ini merupakan salah satu cara dalam menjaga awareness brand dan reputasi ditengah banyaknya competitor dan isu tentang air minum dalam kemasan ini. Dimana inovasi ini tentunya juga disesuaikan dengan kemauan konsumen, hal ini sudah disampaikan narasumber bahwa produk AQUA Life ini terkait dengan banyaknya isu dan permintaan akan produk air minum yang lebih ramah lingkungan, sehingga AQUA menargetkan produk tersebut kepada segmentasi konsumen tertentu sebagai awal mula dari pengenalan produk ini.

\section{Menurut Park}

$(2009: 315)$ manajemen reputasi merek terus menerus. Konsep merek dan citra merek, dan sebagai konsekuensinya reputasi akan dikelola selama masa hidup merek, melalui pemilihan ekspresi merek, pengenalannya di pasar dan perluasan, pertahanan dan penegakan dari waktu ke waktu Pelanggan mengantisipasi suatu merek akan memenuhi harapan mereka, dibentuk oleh reputasi yang ada. Dalam hal ini, pasar mengharapkan konsistensi dari merek, baik dalam hal identitas yang diproyeksikan dan dukungan dari identitas ini. Pelanggan tidak akan menganggap suatu merek sebagai merek yang dapat diandalkan dan dapat dipercaya ketika tidak memberikan apa yang dijanjikannya. Dalam hal ini, reputasi AQUA harus terus dikelola selama hidup merek dan perusahaan harus dapat memenuhi harapan konsumen dan menjaga konsistensi agar reputasi tetap terjaga. Sedangkan menurut Fombrun \& Rindova (2007:343) menjelaskan bahwa reputasi adalah hal yang kurang lebih menguntungkan di mana suatu perusahaan dipegang oleh para pemangku kepentingannya. Pertimbangan semacam itu, yang diterjemahkan ke dalam reputasi yang lebih besar bila dibandingkan dengan perusahaan pesaing, memungkinkan mereka untuk mengatasi sifat persaingan yang ketat dan menawarkan nilai-nilai yang intuitif, relevan, dan disesuaikan untuk pelanggan mereka. Dengan ini Setiap interaksi dengan pelanggan dan pemangku kepentingan lain memengaruhi dan menambah ekuitas merek perusahaan, semakin positif pengalaman pelanggan, semakin kuat merek, dan semakin besar reputasi positif organisasi. Maka dari itu menjaga reputasi dan memiliki reputasi sangatlah penting untuk AQUA dikarenakan nama perusahaan dan reputasi yang sudah baik, pentingnya menjaga reputasi didepan pemangku pementingan dan kompetitor agar ekuitas merek perusahaan terus terjaga, hal ini juga dapat dibentuk dari banyaknya pengalaman pelanggam dan kekuatan merek.

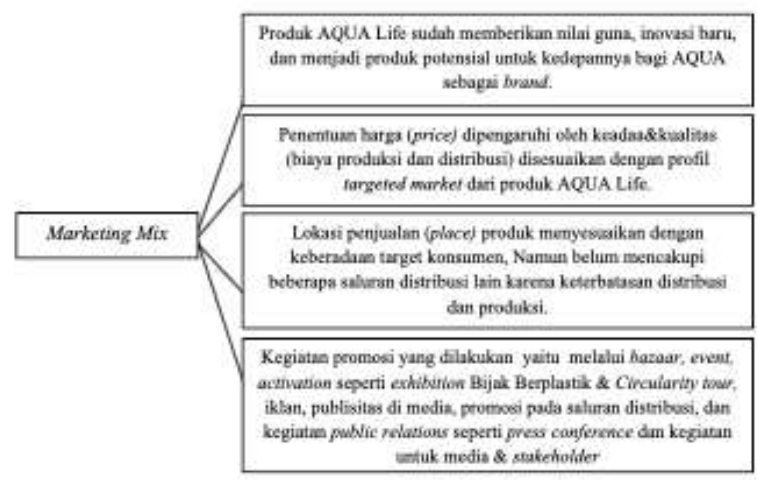

Gambar 14. Marketing Mix

Sumber: Data Wawancara

\section{Model 13 Marketing Mix}

Menurut Kotler \& Armstrong (1997:48) marketing mix adalah perangkat alat pemasaran taktis yang dapat dikendalikan, produk, harga, distribusi, dan promosi yang dipadukan oleh perusahaan untuk menghasilkan respons yang diinginkan dalam target market

Produk AQUA Life sudah memberikan nilai guna yang diinginkan oleh konsumen yaitu sebagai air minum dalam kemasan plastic yang lebih ramah lingkungan. Produk ini merupakan inovasi 
baru dan menjadi produk potensial mengingat produk ini memiliki prospek yang baik untuk penjualan karena kegunaan yang dicari di kalangan konsumen dan masyarakat semua segmentasi.

Penentuan harga (price) dipengaruhi oleh keadaan dan kualitas produk (mencakupi biaya produksi dan distribusi dari produk itu sendiri), target konsumen, dan kondisi pasar dikarenakan produk ini merupakan produk baru yang awam namun diperkuat oleh nama brand. Dimana akumulasi dari biaya tersebut juga disesuaikan dengan profil targeted market dari produk AQUA Life sendiri yaitu kelas ekonomi A-B, Millenials yang berumur 1844 tahun, Perempuan dan laki-laki dengan kriteria memulai sustainable dan healthy lifestyle. Dengan penentuan harga berdasarkan kedua hal tersebut, penetapan harga produk AQUA Life dirasa masih sesuai dan dapat diterima oleh konsumennya.

Lokasi penjualan (place) produk pun menyesuaikan dengan keberadaan target konsumen, dimana produk ini dijual sebagai produk air minum utama di beberapa lokasi dan saluran penjualan yang berada di daerah Jakarta dan Bali sebagai kota yang memiliki existing consumer profile yang sesuai dan jumlahnya cukup banyak. Tempat dan saluran distribusi barang mencakupi retail yaitu melalu minimarket (khusus Bali), wholesale pada supermarket, by agents to consumer and business yang diperuntukan pada restoran dan cafe, direct distribution of business products yaitu untuk distribusi ke perhotelan, wholesale distribution of industrial products melalui mitra bisnis AQUA Home Service (khusus Bali), wholesale distribution to business retailers melalui mitra bisnis AQUA Home Service (khusus Bali).

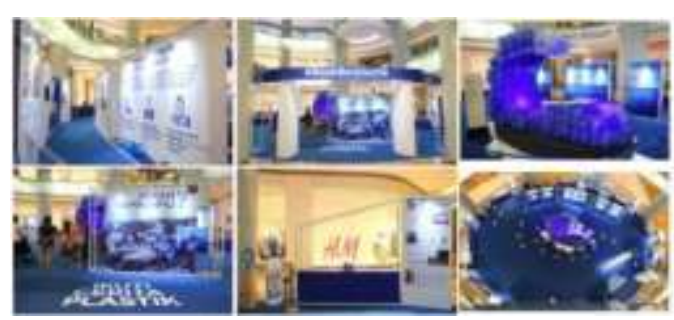

Gambar 15. Lokasi Penjualan

Sumber : Arsip Danone-AQUA

Seluruh kegiatan promosi yang dilakukan sudah melalui perencanaan dengan organisasi dan lembaga terkait agar lebih tempat penyampaian materi komunikasinya. Kegiatan promosi yang dilakukan sudah sesuai dengan kriteria promosi strategi promotion mix, personal selling dilakukan melalui booth, bazaar, dan event Bijak Berplastik yang merupakan activation berupa exhibition, mass selling melalui iklan dan publisitas produk di media (infografis dan artikel), sales promotion melalui SPG yang terdapat dilokasi penjualan produk dan juga media sosial, retail, wholesale, ataupun pada activation, public relations melalui press conference, press release, dan circularity tour yang mencakupi kegiatan media, konsumen, dan stakehokder, dan direct marketing yang dilakukan melalui promosi atau diskon yang disampaikan melalui semua saluran distribusi.

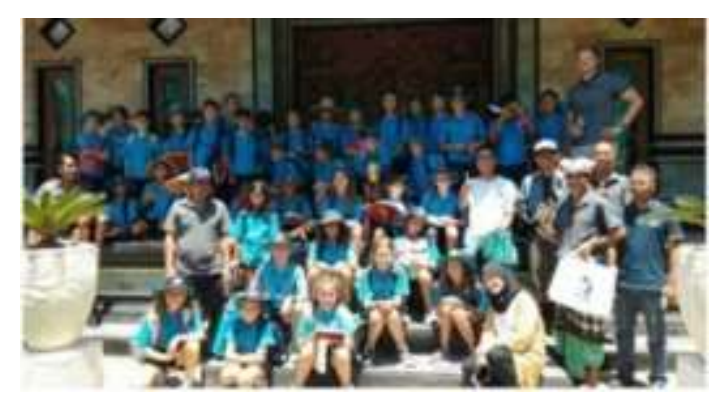

Gambar 16. Kegiatan Promosi

Sumber : Arsip Danone-AQUA

Sebagai produk yang diinginkan sebagai menjadi pelopor, akan lebih baik jika memanfaatkan semua saluran distribusi agar konsumen dpaat mengetahui informasi tentang produk ini dan semua 
strategi promosi dalam marketing mix yang telah dirancang dapat diimplementasikan dan dilaksanakan secara optimal disemua saluran agar konsumen dapat lebih aware dan minat terhadap produk ini. Hal ini sesuai dengan pernyataan Kotler bahwa salah satu faktor yang mempengaruhi minat beli konsumen adalah faktor ketersediaan produk (Kotler, 2005)

Namun, pada kenyataannya hal ini biasa dilakukan pada produk baru yang memiliki manfaat dan segmentasi konsumen yang khusus atau berbeda dari produk lainnya (dalam hal ini jenis produk air minum lainnya). Hal ini dijelaskan oleh Burnett (2018:104) bahwa penting bahwa produk tersebut siap di pasar di kota dan termasuk rantai orang dan organisasi seperti distributor, grosir dan pengecer yang membentuk jaringan distribusi organisasi (saluran distribusi). Organisasi harus memilih apakah akan menjual langsung ke orang atau melalui distributor Sedangkan menurut Connett (2004:10) distribusi produk mencakup semua saluran yang diikuti dalam mentransfer produk kepada konsumen akhir. Proses ini memastikan bahwa produk akan mencapai target pasar di tempat yang tepat, pada waktu yang tepat dan dengan biaya yang tepat. Dari kedua jurnal ini dijelaskan bawa perusahaan memang harus memilih jalur distribusi yang sesuai dengan target konsumen, agar produk bisa sampai kepada target pasar yang tepat dengan perencanaan distribusi yang tepat.

Selain itu menurut Sari (2012) bahwa erusahaan merek menggunakan MPR dan menganggap MPR efektif terutama dalam membangun kesadaran merek (brand awareness) dan pengetahuan merek (brand knowledge) untuk produk baru MPR penekanannya bukan pada selling, namun peran pemberian informasi, pendidikan dan upaya peningkatan pengertian lewat penambahan pengetahuan suatu produk akan lebih kuat dan lama dampaknya dan agar lebih lama diingat konsumen. Terdapat beberapa kegiatan Marketing Public Relations yang dapat dilakukan dan dikembangkan oleh AQUA untuk kedepannya yaitu: (1) Special Event, (2) Publisitas, (3) Sponsorship, (4) Public Service), (5) Publikasi, (6) Media Events, (7) Media tours. (8) Trade support.

Hal ini sesuai juga dengan pernyataan triangulator yang menyarankan bahwa kegiatan CSR ataupun kegiatan yang bersangkutan dengan stakeholder (komunitas), media, dan konsumen dapat dilakukan lebih sering dan lebih meluas, mengingat kegiatan terkait merupakan Circularity Tour, dimana kegiatan ini baru diadakan di 3 kota yaitu Jakarta, Bandung, dan Bali selama total 5 kali. Perusahaan dapat melanjutkan dan menjadwalkan kegiatan ini lebih lanjut agar dapat mencakup audiens yang lebih luas sehingga pengenalan akan produk dan edukasi dari brand pun dilakukan secara continu. AQUA juga dapat membuat iklan layanan masyarakat dengan pendekatan yang sesuai dengan konsep produk yaitu sustainable lifestyle dan menjaga lingkungan bekerjasama dengan stakeholder terkait.

\section{PENUTUP}

\section{Simpulan dan Saran}

Berdasarkan hasil penelitian yang sudah didapat mengenai manajemen brand image-concept AQUA melalui produk AQUA Life berdasarkan tahapan Brand Image-Concept Manegement oleh Lawson \& Balakhirsna (1998), maka dapat diambil kesimpulan bahwa produk AQUA Life telah dikategorikan menjadi produk barang tidak tahan lama (nondurable goods) dan jenis barang konsumen (convenience goods). Pengkategorian produk AQUA Life juga dapat dikategorikan sebagai produk sensorik, agar AQUA dapat menjelaskan informasi produk lebih detail pada pada pasar online agar memuaskan 
informasi dan pengalaman konsumen karena berpengaruh terhadap persepsi, pengalaman, dan daya beli konsumen terhadap produk AQUA Life.

Manfaat produk AQUA Life yang tergolong kepada segmentasi the sociable. Kedepannya manfaat produk dapat dikelompokan berdasarkan fungsional dan psikologis untuk membuka kemungkinan suatu produk dapat menawarkan dua jenis manfaat tersebut mengingat suatu produk pasti memiliki karakteristik mengikuti referensi grup terkait. AQUA sudah mengkategorikan current needs dari konsumennya yaitu pada physical needs yaitu pangan. Analisis minat konsumen secara transaksional, preferensial, dan eksploratif dapat membantu mengetahui seberapa potensial konsumen dalam membeli produk AQUA Life secara berulang, apakah sesuai atau tidak dengan minat konsumen, dan apakah akan digunakan secara continue.

Pada tahap identify potential brand image, jenis objective dari riset yang dilakukan AQUA terhadap produk AQUA Life termasuk ke dalam jenis planning research. AQUA dapat merumuskan masalah penelitian dan hipotesis yang sesuai dengan pernyataan masalah yang terdiri 2 atau lebih variable agar mudah diterjemahkan kedalam pertanyaan. Desain riset yang dilakukan AQUA untuk riset pasar produk AQUA Life yaitu menggunakan descriptive research untuk mengetahui segmentasi konsumen potensial. AQUA dapat mengeksplorasi jenis penelitian studi Cross-sectional dan longitudinal untuk mengetahui peramalan jangka panjang akan produk tersebut.

AQUA melakukan proses data collecting dilakukan oleh research agency dengan melakukan wawancara existing consumer. AQUA dapat memastikan pengumpul data, waktu, dan pengawasan pengambilan data dalam proses ini agar data yang dikumpulkan diyakinin validitasnya. Proses data analysis yang dilakukan dalam market riset ini dilakukan sepenuhnya oleh pihak research agency, AQUA tidak melakukan pemeriksaan kembali (verification) terhadap data yang diambil. Kedepannya AQUA dapat melakukan pretesting sebagai antisipasi jika tidak dapat melakukan validitas data unuk membantu menentukan sampel dan validitas. Hasil dari riset ini dipresentasikan oleh pihak agency kepada pihak AQUA dalam bentuk oral presentation yang berjudul AQUA Consumer Tribes. Kedepannya AQUA dapat membuat dummy untuk membantu menuliskan feedback laporan dari pemegang keputusan setelah selesai dianalisis, agar hasil riset yang dipresentasikan kepads senior atau top management sudah sesuai dengan model presentasi perusahaan tersebut agar lebih mudah dimengerti..

Pada tahap identify brand concept, pemetaan produk sesuai konsep fungsional Secara fungsional produk AQUA Life memiliki fungsi produk utama yaitu untuk memenuhi kebutuhan hidrasi sehat. Kedepannya produk AQUA Life dapat memiliki fungsi dalam product solving specialization strategy untuk menentukan spesialisasi yang lebih dan pasar menjadi lebih terfragmentasi,

Pengonsepan produk simbolik digambarkan melalui visual kemasan dan juga refrensi grup atau target konsumen terkait melalui Brand Ambassador. Pengkomunikasian asosiasi simbolik produk AQUA Life melalui atribut simbolik (packaging, logo, dan kemasan) yang dapat menaikkan ego kelompok sosial tersebut dan juga menyesuaikan dari waktu ke waktu.

Pengonsepan produk AQUA Life secara experiential AQUA ingin membuat konsumennya lebih merasa environtmentally friendly dan penggunaan botol layaknya tumbler. Namun hal ini tidak disetujui oleh konsumen karena adanya feedback dari konsumen tentang 
material plastic dan ketebalan kemasan yang dirasa lembek sehinga kurang merangsang panca indera dan kognitif. Peningkatan pengalaman penggunaan produk dapat dioptimalkan melalui activation, dan memaksimalkan penggunaan iklan dan komunikasi pemasaran, termasuk situs Web dalam menyampaikan pengalaman produk (testimoni) AQUA Life kepada consumen.

Pada tahap selecting a brand image concept strategy, AQUA sudah cukup mendapatkan pengakuan, reputasi, hubungan baik, dan berinovasi dengan produk AQUA Life untuk menentukan image kedepannya agar lebih mudah.. Maka dari AQUA menjaga reputasi didepan pemangku pementingan dan kompetitor dengan menjaga interaksi dengan pelanggan, pemangku kepentingan agar ekuitas merek perusahaan terus terjaga, hal ini juga dapat dibentuk dari banyaknya pengalaman positif pelanggan, stakeholder dan kekuatan merek.

Pada aspek marketing mix, secara produk AQUA Life sudah memberikan nilai guna yang diinginkan oleh konsumen. Penentuan harga (price) dipengaruhi oleh keadaan dan kualitas produk (produksi dan distribusi), target konsumen, dan kondisi pasar sebagai produk baru. Dari aspek place atau saluran distribusi barang, AQUA belum baru mendistribusikan 6 dari 8 saluran distribusi, kedepannya, AQUA dapat memenuhi saluran distribusi seperti direct distribution dan distribution through broker, dan memenuhi saluran distribusi dan pasar agar jenis produk ini sampai ke tangan konsumen sasaran dengan biaya dan waktu distribusi yang tepat.

Kegiatan promosi yang dilakukan sudah yaitu melalui booth, bazaar, dan event Bijak Berplastik, mass selling melalui iklan dan publisitas, sales promotion melalui SPG, public relations melalui press conference, press release, dan circularity tour yang mencakupi kegiatan media, konsumen, dan stakehokder, dan direct marketing yang dilakukan melalui promosi. Pengoptimalkan kegiatan Marketing Public Relations melalui kegiatan Circularity Tour agar pengetahuan produk AQUA Life lebih meluas kepada stakeholder tekait.

\section{DAFTAR PUSTAKA}

Abimbola, \& Vallaster. (2007). Brand, organisational identity and reputation in SMEs: an overview. Qualitative Market Research: An International Journal , 10(4), 341345.

Ardianto, Elvinaro. (2011). Metodologi Penelitian untuk Public Relations Kuantitatif dan Kualitatif. Bandung: Simbiosa Rekatama Media.

Keller, Kevin Lane (2012). Strategy Brand Management Building, Measuring, and managing Brand Equity, $4^{\text {th }}$ Edition. New Jersey : Prentice Hall Kotler

Moleong, Lexy. J. (2012). Metodologi Penelitian Kualitatif. Bandung: PT Remaja Rosdakarya.

Ahmad, R. (2003). Benefit Segmentation: A potentially useful technique of segmenting and targeting older consumers. International Journal of Market Research, 45(3).

Aji, Angga. (2014). Strategi Penggunaan Media Sosial Untuk Meningkatkan Brand Image. Universitas Gadjah Mada.

Atnan. (2014). Analisis Pengaruh Persepsi Kualitas, Ketersediaan Produk, Product Knowledge Terhadap Brand Awareness Produk Private Label. 
Brakus, Schmitt, \& Zarantonello. (2019). Brand Experience: What Is It? How Is It Measured? Does It Affect Loyalty? American Marketing Association, 73, 52-68.

Cho, Y. (2003). The impact of product category customer dissastification in cyberspace.

Connet. (2004). Marketing and Promotional Mix. Universiteit of Petroria, 2.

Dian, Nuranindya. (2016). Proses Pembentukan Brand Awareness dan Brand Image Melalui Penerapan Integrated Marketing Communication (IMC). Universitas Indonesia.

Halim, R., \& Zulkarnain, E. (2017). The Effect of Consumer Affinity and Country Image Toward Wiilingness to Buy.

Hamid, Rasool, Kiyani, \& Ali. (2012). Factors Affecting the Brand Recognition; An Exploratory Study. Global Journal of Management and Business Research, 12(7), 75-78.

Hyman, \& Sierra. (2015). Marketing Research Process : Six Stages.

Jain, M. (2013). An Analysis of Marketing Mix: 7Ps or More. Asian Journal of Multidisciplinary Studies, 1(4), 2327.

Khurram, M., Qadeer, \& Muhammad, S. (2018). The Role of Brand Recall, Brand Recognition and Price Consciousness in Understanding Actual Purchase.

Khurram, Qadeer, \& Sheeraz. (2018). The Role of Brand Recall, Brand Recognition and Price Consciousness in Understanding
Actual Purchase. Journal of Research in Social Sciences, 6(2), 219-227.

Langseng, E. (2014). A Typology of Consumption Value. Scandinavian Journal of Business Research, 28, 107-117.

Lawson, R., \& Subra, B. (1998). Developing and Managing Brand Image and Brand Concept Strategies. Developing and Managing Brand Image and Brand Concept Strategies, 123.

Max, \& Neef. (2017). Development and human needs .

Muliawan, \& Sugiarto. (n.d.). Pengaruh Food Quality dan Ketersediaan Produk Terhadap Repurchase Intention Produk Sari Roti di Surabaya . 1-3.

Park, Jaworski, \& MacInnis. (1986). Strategic Brand Concept Management.

Pratama, Agrie. (2012). Peran Social Media Dalam Membangun Brand Image Guna Mempertahankan Corporate Image. Universitas Indonesia.

Setiawan, \& Fadillah. (2014). Tinjauan Atas Penetapan Harga Produk Peralatan Kesehatan Pada PT. Rivi Utama. 1-20.

Smith, S., \& Albaum, G. (2012). Basic Marketing Research.

Solomon. (1963). The Role of Products as Social Stimuli: A Symbolic Interactionism Perspective. Journal of Consumer Research, 10.

Srivastava, Alpert, \& Shocker. (1984). A Customer- oriented Approach for Determining Market Structure. Journal of Marketing Research 
Collection Lee Kong Chian School Of Business, 48(2), 35-42.

Puspita, Sondang. 2008. Efektivitas Kegiatan Marketing Public Relations Centro Plaza Semanggi Terhadap CustomerSatisfication. Universitas Indonesia, 11-13

Thabit, \& Raewi. (2018). The Evaluation of Marketing Mix Elements:. International Journal of Social Sciences \& Educational Studies, 4(4), 100-104.

Thomson, MacInnis, \& Park. (2005). The Ties That Bind: Measuring the Strength of Consumers'Emotional Attachments to BrandsTHE. Jounal of Consumer Psychology, 15(1), 7791.
Velotsou, \& Suffolk. (2009). Brand Relationship Through Brand Reputation and Brand Tribalism. Journal of Business Research, 314322.

Venessa, \& Arifin. (2014). Pengaruh Citra Merek (Brand Image) dan Harga Terhadap Keputusan Pembelian Konsumen.

Wijaya. (2013). Dimensions of Brand Image: A Conceptual Review from the Perspective of Brand Communication. European Journal of Business and Management, 5(31), 55-63.

Winzar, H. (1992). Product Classification and Marketing Strategy. 262. 